\title{
THE
}

\section{Significance of Population Centers As Sources of Gaseous and Dissolved PAHs in the Lower Great Lakes}

Carie A. McDonough

Mohammed A. Khairy

Derek C G Muir

Rainer Lohmann

University of Rhode Island, rlohmann@uri.edu

Follow this and additional works at: https://digitalcommons.uri.edu/gsofacpubs

The University of Rhode Island Faculty have made this article openly available.

Please let us know how Open Access to this research benefits you.

This is a pre-publication author manuscript of the final, published article.

Terms of Use

This article is made available under the terms and conditions applicable towards Open Access Policy Articles, as set forth in our Terms of Use.

\section{Citation/Publisher Attribution}

McDonough, C. A., Khairy, M A., Muir, D. C. G., \& Lohmann, R. (2014). Significance of population centers as sources of gaseous and dissolved PAHs in the lower Great Lakes. Environmental Science \& Technology, 48(14), 7789-7797. doi: 10.1021/es501074r

Available at: http://dx.doi.org/10.1021/es501074r

This Article is brought to you for free and open access by the Graduate School of Oceanography at DigitalCommons@URI. It has been accepted for inclusion in Graduate School of Oceanography Faculty Publications by an authorized administrator of DigitalCommons@URI. For more information, please contact digitalcommons-group@uri.edu. 
1 THE SIGNIFICANCE OF POPULATION CENTERS AS SOURCES OF GASEOUS AND

2 DISSOLVED PAHS IN THE LOWER GREAT LAKES

3 Carrie A. McDonough ${ }^{1}$, Mohammed Khairy ${ }^{1,2}$, Derek Muir ${ }^{3}$, Rainer Lohmann ${ }^{1 *}$

$4 \quad{ }^{1}$ University of Rhode Island Graduate School of Oceanography,

5215 S. Ferry Road, Narragansett, RI 02882, USA

$6 \quad{ }^{2}$ Alexandria University Department of Environmental Sciences, Alexandria, Egypt

$7 \quad{ }^{3}$ Environment Canada, Aquatic Contaminants Research Division, Burlington, ON, Canada

8 "Corresponding Author

9 TOC ART

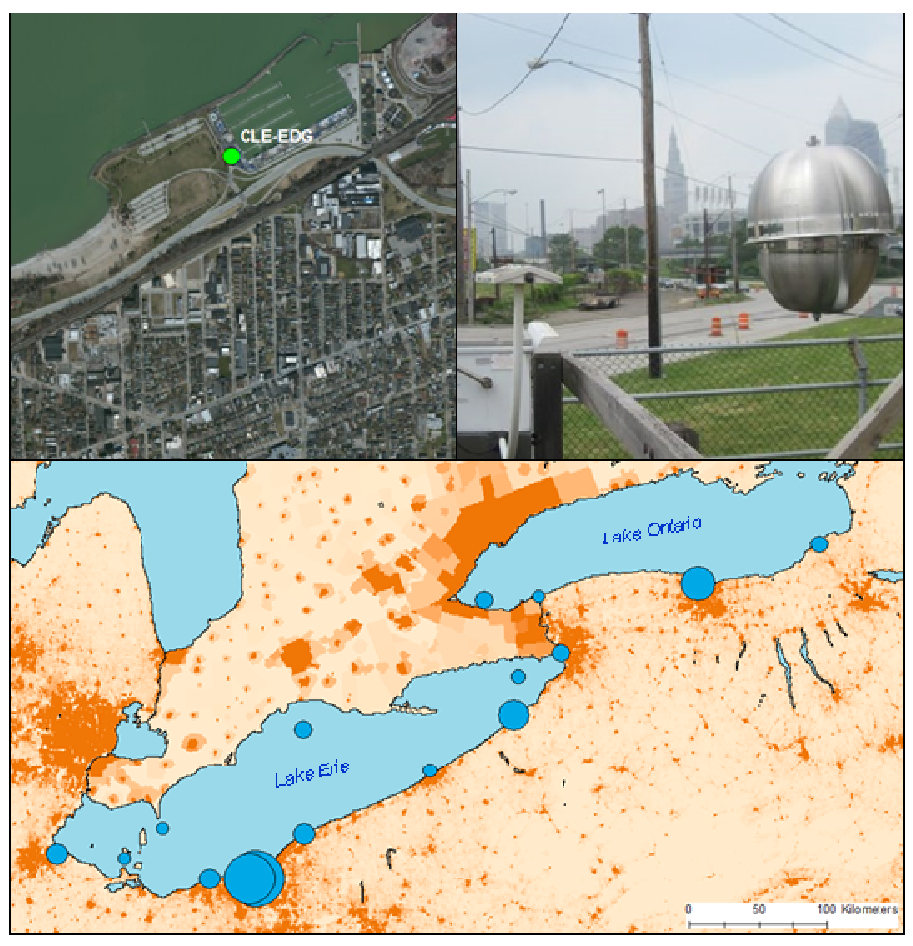




\section{ABSTRACT}

Polyethylene passive samplers (PEs) were used to measure concentrations of gaseous and

13 dissolved polycyclic aromatic hydrocarbons (PAHs) in the air and water throughout the lower

14 Great Lakes during summer and fall of 2011. Atmospheric ${ }_{15 \mathrm{PAH}}$ concentrations ranged from 2.1

$15 \mathrm{ng} / \mathrm{m}^{3}$ in Cape Vincent (NY) to $76.4 \mathrm{ng} / \mathrm{m}^{3}$ in downtown Cleveland (OH). Aqueous ${ }_{18 \mathrm{PAH}}$

16 concentrations ranged from $2.4 \mathrm{ng} / \mathrm{L}$ at an offshore Lake Erie site to $30.4 \mathrm{ng} / \mathrm{L}$ in Sheffield Lake

$17(\mathrm{OH})$. Gaseous PAH concentrations correlated strongly with population within 3-40 $\mathrm{km}$ of the

18 sampling site depending on the compound considered, suggesting that urban centers are a

19 primary source of gaseous PAHs (except retene) in the lower Great Lakes region. The

20 significance of distant population (within $20 \mathrm{~km}$ ) versus local population (within $3 \mathrm{~km}$ ) increased

21 with sub-cooled liquid vapor pressure. Most dissolved aqueous PAHs did not correlate

22 significantly with population, nor were they consistently related to river discharge, wastewater

23 effluents, or precipitation. Air-water exchange calculations implied that diffusive exchange was a

24 source of phenanthrene to surface waters, while acenaphthylene volatilized out of the lakes.

25 Comparison of air-water fluxes with temperature suggested that the significance of urban centers

26 as sources of dissolved PAHs via diffusive exchange may decrease in warmer months. 
INTRODUCTION

Polycyclic aromatic hydrocarbons (PAHs) are ubiquitous pollutants that originate from

31 oil spills as well as anthropogenic and natural combustion processes. Major sources include

32 fossil fuel combustion, metal production, waste incineration, residential and commercial biomass

33 burning, and vehicular emissions. ${ }^{1-5}$ PAHs are often associated with densely populated areas,

34 especially in industrialized countries. ${ }^{3,4,67}$ PAHs and their transformation products are a primary

35 carcinogenic component of urban air pollution and health effects resulting from chronic exposure

36 are a serious concern. ${ }^{8,9}$

37 Polyethylene passive samplers (PEs) are cost-effective, simple tools with lower detection

38 limits than traditional active sampling techniques. Instead of pumping air or water through a

39 filter, PEs accumulate hydrophobic organic contaminants (HOCs) over time via diffusion,

40 accumulating only truly dissolved or gas-phase molecules. ${ }^{10}$ Concentrations of truly dissolved

41 HOCs are of interest because this fraction is available for direct diffusive exchange between

42 water and other reservoirs such as air, biota, or sediment.

43 The use of PEs facilitates simultaneous spatially resolved measurements and calculations

44 of air-water diffusive exchange rates. For most HOCs, concentrations measured by PEs reflect a

45 time-integrated concentration representative of the entire deployment period. For compounds

46 that equilibrate during deployment, concentrations reflect the most recent concentration the

47 sampler was exposed to. PEs have previously been used to measure HOCs in water and air ${ }^{11-13}$

48 and to calculate air-water gradients of HOCs, but this method has not been applied to the lower

49 Great Lakes. ${ }^{14-16}$

50 Lake Erie and Lake Ontario are the smallest of the Great Lakes by volume and have

51 estimated residence times of 2.7 and 7.5 years, respectively. ${ }^{17}$ About $80 \%$ of Lake Erie's water is 
52 supplied by the Detroit River, which is fed by Lake Huron via Lake St. Claire. Among the Great

53 Lakes, Lake Erie is the shallowest (average depth $19 \mathrm{~m}$ ), warmest, and most biologically

54 productive. ${ }^{18,19}$ Lake Ontario is much deeper (average depth $86 \mathrm{~m}$ ) and primarily receives water

55 from Lake Erie via the Niagara River. ${ }^{19}$ Currents in the Great Lakes are weak (a few cm/s) with

56 complex temporal variability that depends on recent atmospheric conditions. In the summertime,

57 circulation is generally counterclockwise. ${ }^{20}$ The lakes are stratified from May through October

58 and well-mixed for the remainder of the year. ${ }^{20}$

59 Heavy urbanization and valuable ecosystems often coincide along the shores of the lower

60 Great Lakes. Atmospheric deposition from urban sources has been identified as a major source

61 of gaseous and particle-bound HOCs to the region's aquatic environment. ${ }^{2,7,21,22}$ Concentrations of

62 total atmospheric PAHs have been shown to correlate strongly with population in this region and

63 urban centers have been linked to significantly increased loadings of contaminants to the

64 lakes. $^{23,24}$ In some cases, however, the lakes have been found to act as a source of HOCs via

65 revolatilization. ${ }^{25,26}$ Much of the previous work describing sources of atmospheric pollution to the

66 Great Lakes is based on a limited number of air monitoring sites as part of the Integrated

67 Atmospheric Deposition Network (IADN). While this data is indispensible in determining

68 baseline concentrations and temporal trends of POPs in the Great Lakes, more detailed

69 knowledge of spatial trends is crucial to identify major sources and transport pathways.

70 The objectives of this study were to (1) provide baseline concentrations of gaseous and

71 dissolved PAHs in Great Lakes air and water, (2) evaluate the importance of urban regions as

72 sources of dissolved PAHs by investigating the relationship between population and PAH

73 concentration, and (3) determine whether the lower Great Lakes are sources or sinks for

74 dissolved PAHs.

75 MATERIALS AND METHODS 
76 Passive Sampling Procedures. A map of all air and water sites and a table outlining temporal

77 coverage and meteorology are provided in the Supporting Information (Figure S1, Table S1 \&

78 S2) along with information on sampler preparation and deployment. PEs were spiked with

79 performance reference compounds (PRCs) via a method adapted from Booij et al. ${ }^{27}$ and sent to

80 trained volunteers throughout the Great Lakes region with the aim of completing three 8-week

81 deployments at each site. After deployment, volunteers returned samplers via overnight delivery.

82 Four sites formed an east-west transect along Lake Ontario's southern shore. The

83 westernmost site, Grimsby (ON), was an offshore buoy monitored by Environment Canada. On

84 Lake Erie, samplers were deployed at nine US shoreline sites and six offshore sites monitored by

85 Environment Canada. Samplers were deployed at the offshore sites once, during late summer.

86 Samplers at Gibraltar Island $(\mathrm{OH})$ and Toledo $(\mathrm{OH})$ were deployed once during late spring/early

87 summer.

88 Meteorological Information \& Site Characteristics. Monthly wind speed averages during the

89 sampling campaign ranged from $3.8 \mathrm{~m} / \mathrm{s}$ in July to $6.1 \mathrm{~m} / \mathrm{s}$ in November, with the greatest

90 average wind speeds offshore of Toledo. Average air temperatures ranged from $7.7^{\circ} \mathrm{C}$ in April to

$9124.3^{\circ} \mathrm{C}$ in July and the mean deployment temperature for all sampling periods was $18.6 \pm 1.8^{\circ} \mathrm{C}$.

92 Surface water temperatures were generally very similar to air temperatures and ranged from

$933.7^{\circ} \mathrm{C}$ (Lake Ontario in May) to $25.1^{\circ} \mathrm{C}$ (Lake Erie in July). ${ }^{28}$ There were westerly prevailing

94 winds during the sampling campaign for most of the study region (Figure S2). ${ }^{29}$ Precipitation and

95 river discharge were lowest during June and July while flows in late spring and early fall were

96 similar. ${ }^{30}$ Locations near major rivers are listed in Table S4.

97 Sample Analysis. All PEs were spiked with deuterated PAHs and extracted twice, each time for

9818 hours. Air PEs were extracted with ethyl acetate followed by hexane. Aqueous PEs were

99 extracted with dichloromethane followed by hexane. Extracts were concentrated to 
100 approximately $100 \mu \mathrm{L}$ and p-terphenyl- $\mathrm{d}_{14}$ was added as an injection standard. Extracts were 101 analyzed using an Agilent $6890 \mathrm{GC}$ coupled to an Agilent $5973 \mathrm{MSD}$ in EI+ selected ion 102 monitoring (SIM) mode. PAH analysis and quality control procedures are further outlined by 103 Khairy et al. ${ }^{11}$

104 PAH concentrations were corrected for internal standard recoveries (Table S5) and blank105 subtracted using the field blank relevant to the sampling site. If no field blank for the site was 106 available, the average concentration from all available field blanks was used. More information 107 on quality assurance and quality control is in the Supporting Information.

109 Determination of Sampling Rate and Ambient Concentration. The uptake of HOCs by PEs is 110 described in detail by Lohmann ${ }^{31}$ and PE-air partitioning is detailed by Khairy et al. ${ }^{11}$ To 111 determine ambient PAH concentrations from concentrations in polyethylene, site-specific 112 sampling rates were estimated via a method adapted from Booij et al. ${ }^{32}$ Further details are 113 provided in the Supporting Information. The average air sampling rate was $28 \pm 17 \mathrm{~m}^{3} /$ day and the 114 average aqueous sampling rate was $112 \pm 57 \mathrm{~L} /$ day (for more details, see SI and Tables S1 and 115 S2).

116 Physico-chemical Parameters. Sampler-matrix partition coefficients $\left(\mathrm{T}=25^{\circ} \mathrm{C}\right)$ used to calculate

117 ambient concentrations for each PAH are listed in Table S7, along with other physico-chemical 118 properties. Temperature-adjusted partition coefficients were obtained using mean temperature 119 during the deployment period for the nearest meteorological buoy or weather station and the 120 modified van't Hoff equation, as in Khairy et al. ${ }^{11}$ The enthalpy of vaporization $\left(\mathrm{H}_{\text {vap }}\right)$ was used

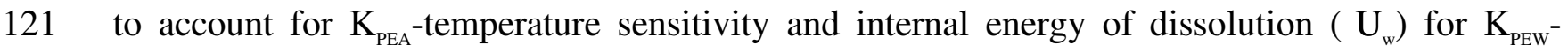
122 temperature sensitivity. 
123 Population Analysis. Population data for each sampling site are presented in Table S8. Total 124 population within a circular area with a 1-cell (about $1 \mathrm{~km}$ ) radius was calculated using the Focal 125 Statistics tool in ArcMap. The process was repeated for larger radii to create a dataset of the total 126 population within $1,2,3,5,10,15,20,25,30,40$, and $50 \mathrm{~km}$ of each of the sampling locations.

127 More information about the population dataset used is available in the Supporting Information.

128 Air-Water Exchange Rates. The difference in equilibrium concentrations of an HOC in two 129 PEs deployed in different matrices is proportional to the difference in the compound's chemical 130 activity between those two matrices. ${ }^{14,15}$ Air-water exchange gradients can therefore be

131 determined from the ratio of PAH concentrations in PEs deployed simultaneously in air and 132 water, corrected to equilibrium concentrations using PRC loss data. Details of air-water 133 exchange calculations are shown in the Supporting Information.

\section{RESULTS AND DISCUSSION}

135 PAHs in Air. Average atmospheric ${ }_{15 \mathrm{PAH}}$ ranged from $2.1 \mathrm{ng} / \mathrm{m}^{3}$ in Cape Vincent (NY) to 76.4 $136 \mathrm{ng} / \mathrm{m}^{3}$ at George T. Craig air sampling station in downtown Cleveland $(\mathrm{OH})$. The spatial 137 distribution of ${ }_{15 \mathrm{PAH}}$ is shown in Figure 1A. Concentrations of all PAHs during each deployment 138 are detailed in Table S9. Gaseous PAHs were dominated by phenanthrene $(28-60 \%)$ and 139 fluorene $(6-48 \%)$ (Figure S4). Typical concentrations ranged from below the detection limit to $14040.3 \mathrm{ng} / \mathrm{m}^{3}$ and $14.6 \mathrm{ng} / \mathrm{m}^{3}$ for phenanthrene and fluorene, respectively. Methylphenanthrenes 141 accounted for $3-5 \%$ of ${ }_{15 \mathrm{PAH}}$ at the offshore sites and $6-10 \%$ of ${ }_{15 \mathrm{PAH}}$ at shoreline sites. 4-5-ring 142 PAHs made up no more than $10 \%$ of total PAHs, with PAHs of greater molecular weight than 143 chrysene (high molecular weight (HMW) PAHs) accounting for $<1 \%$ of ${ }_{15 \mathrm{PAH}}$. Ratios of gaseous 144 Flra/Flra+Pyr were 0.6 and Phn/ MPhns $>1$ at all sites, suggesting that gaseous PAHs were 145 primarily combustion-derived. ${ }^{33}$ 
The two sites in Cleveland consistently displayed the greatest concentrations of gaseous

147 PAHs except retene throughout the deployment season. Retene is often considered to be

148 indicative of wood smoke or pulp/paper mill effluent, as opposed to fossil fuel combustion. ${ }^{34,35}$

149 Retene was greatest west of Cleveland in Sheffield Lake, but even here accounted for less than

$150 \quad 0.7 \%$ of total gaseous PAHs. In contrast, Ruge found retene to be a significant component of 151 gaseous PAH profiles at many sites on Lake Superior. ${ }^{36}$

152 Principal component analysis (PCA) using the FactoMineR package ${ }^{37}$ in the statistical

153 programming language $\mathrm{R}^{38}$ was employed to visualize similarities and differences between PAH

154 profiles (Figure S5). Profiles were similar at all sites with the exception of Sheffield Lake,

155 Rochester, and the Cleveland sites, which were clustered separately. The clustering of most sites

156 in the same region of the plot suggests that sources of PAHs were similar across the study region.

157 Profiles in Cleveland may have been distinct due to nearby point sources. In addition to impacts

158 from vehicular emissions associated with heavy traffic in downtown areas, these sites were

159 within $5 \mathrm{~km}$ of a greater number of industrial point sources (primarily chemical manufacturing,

160 petroleum industry, and metalworking facilities) when compared to the other sites using the EPA

161 Toxic Release Inventory (TRI). ${ }^{39}$

162 Comparison with Literature Values. Sun et al. reported mean gaseous concentrations for

163 the 1990 s to 2003 of 16 PAHs, 13 of which were measured here. ${ }^{23}$ They reported $7.2 \mathrm{ng} / \mathrm{m}^{3}$ at 164 Sturgeon Point, a semi-urban site south of Buffalo, $1.2 \mathrm{ng} / \mathrm{m}^{3}$ at Point Petre, a northern Lake 165 Ontario site representative of background, and $73.4 \mathrm{ng} / \mathrm{m}^{3}$ in Chicago (IL). ${ }^{23}$ Concentrations of 166 individual PAHs in Cleveland reported here were comparable to those reported by IADN for 167 Chicago. Gaseous PAH profiles showed dominance of phenanthrene and fluorene, as reported 168 here. 
PAH concentrations in this study were comparable to those measured by Ruge at urban

170 locations along the shore of Lake Superior. ${ }^{36}$ Melymuk et al. measured a total gaseous PAH 171 concentration of $51 \mathrm{ng} / \mathrm{m}^{3}$ in downtown Toronto (ON), comparable to Cleveland and Rochester

172 concentrations in this study. ${ }^{6}$ Concentrations in this study were lower than those reported for 173 Alexandria, Madrid, or Lake Chaohu, China and greater than concentrations on the Taiwan 174 coast. ${ }^{11,40-42}$ Total (aerosol and dissolved) 2-3-ring PAHs near Lake Victoria, East Africa were 175 lower than 2-3-ring gaseous PAHs in Cleveland, but greater than the remainder of the 176 deployment sites. ${ }^{43}$

177 Gaseous PAHs and Population. Sampling sites were classified as urban, semi-urban, 178 rural, or remote based on population within $3 \mathrm{~km}$ (Table S8). Mean ${ }_{15 \mathrm{PAH}}$ for each type of site are 179 summarized in Table 1. For both lakes, the greatest concentrations of gaseous PAHs were 180 observed at urban sites. However, ${ }_{15 \mathrm{PAH}}$ was not significantly different based on site classification 181 using a one-way ANOVA ( $\mathrm{p}>0.05)$. There were no obvious changes in PAH profile 182 composition based on whether the site was urban, semi-urban, rural, or remote (Figure S4).

183 To explore relationships with population in more detail, population within discrete radii 184 of 1 to $40 \mathrm{~km}$ from each site were compared to average atmospheric $\mathrm{PAH}$ concentrations to 185 determine the importance of local versus distant contributions in determining PAH 186 concentrations. Total gaseous PAHs correlated most strongly with population within a $20 \mathrm{~km}$ 187 radius around each site $\left(\mathrm{r}_{20 \mathrm{~km}}^{2}=0.73, \mathrm{p}<0.001, \mathrm{n}=17, \mathrm{SE}=11.3\right)$ (Figure 2). Significant 188 correlations $\left(0.58<\mathrm{r}^{2}<0.77, \mathrm{p}<0.001\right)$ were observed for all measured PAHs at some radius, 189 with retene exhibiting the weakest correlation $\left(\mathrm{r}_{1 \mathrm{~km}}^{2}=0.30\right.$ at a radius of $1 \mathrm{~km}, \mathrm{p}=0.02$, $190 \mathrm{SE}=0.02$ ). This is most likely due to retene's association with wood smoke, as opposed to fossil 191 fuel combustion. ${ }^{34,35}$ Strong correlations suggest that urban centers are a primary source of 192 gaseous PAHs (except retene) in the lower Great Lakes region. 
For each $\mathrm{PAH}$, the strength of the correlation between population and concentration

194 varied as we changed the radius used to characterize population at the site (Figure 3). All 195 compounds except retene displayed a bimodal relationship, with two radii of maximum 196 correlation. This relationship was less pronounced for the low molecular weight (LMW) PAHs 197 than HMW PAHs. Strong similarities between correlation profiles (e.g., the 5-ring PAHs) 198 suggest similar sources and affinities for transport.

199 Hafner and Hites suggested that the significance of local sources in determining Great 200 Lakes HOC concentrations varies based on a compound's atmospheric lifetime. ${ }^{7}$ The 201 atmospheric lifetimes of gaseous PAHs is determined primarily by susceptibility to hydroxyl 202 degradation and gas-particle partitioning. ${ }^{7}$ Anthracene exhibited a distinctly shaped correlation 203 curve with two maxima at radii $25 \mathrm{~km}\left(\mathrm{r}_{25 \mathrm{~km}}^{2}=0.77\right)$ and $5 \mathrm{~km}\left(\mathrm{r}_{5 \mathrm{~km}}^{2}=0.77\right)$. Anthracene has a 204 shorter lifetime (1.5 hrs) with respect to hydroxyl radical degradation relative to other PAHs, 205 which may explain why stronger correlation is observed at short distances than for other 3-ring 206 PAHs. ${ }^{44,45}$ However this does not explain the comparable correlation at $25 \mathrm{~km}$. Acenaphthylene is 207 expected to have a similar lifetime to anthracene $(1.6 \mathrm{hrs})^{44}$ and exhibited stronger correlations 208 with more local population than fluorene (Figure 3).

209 Fluorene is often observed to be more stable with respect to photochemical oxidation 210 than similarly-sized PAHs (average lifetime $22-26 \mathrm{hrs}$ ), ${ }^{44,46}$ but more distant sources did not 211 become more significant for this compound due to its longer lifetime. Fluorene correlated less 212 strongly with population than acenaphthylene at all radii, but the divergence was largest at 213 shorter distances. Gaseous HMW PAHs are expected to have short atmospheric residence times 214 due to reaction with hydroxyl radicals, which may contribute to the increased relevance of local 215 versus long-range sources that was observed for these compounds. ${ }^{7}$ These results suggest that 216 reaction with hydroxyl radicals limited the importance of sources distant from sampling sites. 
The degree to which a given PAH partitions from gaseous to particulate phase, and thus

218 is not detected by PEs, depends on the composition and concentration of ambient aerosol as well

219 as temperature and vapor pressure. ${ }^{47-49}$ Sub-cooled liquid vapor pressures $\left(\mathrm{p}_{\mathrm{L}} / \mathrm{Pa}\right)$ for all PAHs

220 (except methylphenanthrenes and retene, for which data was not available) were determined for

221 average deployment temperature $\left(18.6^{\circ} \mathrm{C}\right)$ using empirical regressions from Paasivirta et al. ${ }^{50} \mathrm{Log}$

$222\left(\mathrm{p}_{\mathrm{L}} / \mathrm{Pa}\right)$ was plotted against the radius where maximum population-concentration correlation was

223 seen for each compound in Figure S6. Excluding anthracene, PAHs with $\mathrm{p}_{\mathrm{L}}>10^{-4} \mathrm{~Pa}$ were most

224 highly correlated with population within a $20 \mathrm{~km}$ radius, while PAHs with $\mathrm{p}_{\mathrm{L}}<10^{-4} \mathrm{~Pa}$ were most

225 highly correlated with population within $3 \mathrm{~km}$. Other studies have observed similar values for $\log \left(\mathrm{p}_{\mathrm{L}}\right)$ at which PAHs transition from being primarily gaseous to particle-bound. ${ }^{26,51,52}$

While Figure S6 highlights maximum correlation, many PAHs exhibited significant

228 correlation with population at both $20 \mathrm{~km}$ and $3 \mathrm{~km}$. As shown in Figure 4, the relative

229 significance of correlation at $20 \mathrm{~km}$ versus $3 \mathrm{~km}\left(\mathrm{r}_{20 \mathrm{~km}}^{2} / \mathrm{r}_{3 \mathrm{~km}}^{2}\right)$ was significantly correlated with

$230 \log \left(\mathrm{p}_{\mathrm{L}}\right)\left(\mathrm{r}^{2}=0.62, \mathrm{p}<0.005, \mathrm{n}=13, \mathrm{STE}=0.1\right)$, suggesting the existence of two sources of

231 varying importance depending on PAH volatility. The relatively greater importance of local

232 sources in determining concentrations of gaseous HMW PAHs could be due to the partitioning of

233 these compounds to relatively cleaner background aerosols at remote sites as described by

234 Gustafson et al. ${ }^{53}$ Due to their lower vapor pressure, gaseous HMW PAHs are more likely than 2-

235 3-ring PAHs to partition into the particulate phase where they will not be measured by PEs and 236 may be deposited more readily via wet or dry deposition. ${ }^{42,54,55}$

237 Previous studies have reported that coastal areas receiving cleaner air from over water 238 bodies exhibit lower atmospheric PAH concentrations than would be predicted based on 239 surrounding population. ${ }^{56}$ Concentrations of total atmospheric PAHs were lower in Buffalo and 240 Oswego than Cleveland or Rochester, though these sites were classified similarly in terms of 
241 population. One explanation is that prevailing westerly winds brought over-lake air towards

242 Buffalo and Oswego, diluting the urban plume. Offshore measurements confirmed that air 243 masses over Lake Erie had relatively lower PAH concentrations than shoreline sites (Table 1).

244 Likewise, the offshore site near Grimsby was closer to the shoreline and more likely to be 245 impacted by westerly air masses arriving over land from Hamilton (ON).

246 To further explore this hypothesis, 6-hour HYSPLIT back trajectories were calculated

247 every 24 hours during the entire deployment period at Cleveland, Buffalo, Rochester, and 248 Oswego using EDAS 40km archived meteorology . The number of trajectories arriving from 249 over water versus over land was counted (Table S3). This analysis supports the idea that 250 Oswego's urban plume could be diluted by over-water air masses, but shows that Buffalo and 251 Cleveland received similar amounts of air traveling from over water and over land.

252 Another explanation for lower concentrations at Oswego and Buffalo could be the 253 amount or type of industry nearby. $\mathrm{EPA} \mathrm{TRI}^{39}$ reported 109, 54, and 37 regulated facilities within $25420 \mathrm{~km}$ of Cleveland Edgewater, Buffalo, and Rochester, respectively, but there were only 4 255 within $20 \mathrm{~km}$ of Oswego. However, this does not explain lower PAH concentrations at Buffalo 256 and it is difficult to use the TRI data to accurately gauge the volume of relevant emissions near 257 each site.

258 PAHs in Water. Average concentrations of ${ }_{18 \mathrm{PAH}}$ ranged from $2.38 \mathrm{ng} / \mathrm{L}$ off Long Point (Stn 259 452) to $30.4 \mathrm{ng} / \mathrm{L}$ in Sheffield Lake, directly west of Cleveland (Figure 1B, Table S10). Average 260 dissolved ${ }_{18 \mathrm{PAH}} \mathrm{S}$, shown in Table 1, were somewhat greater in Lake Erie than in Lake Ontario 261 when similar sites were compared, but not significantly (one-way ANOVA, p > 0.05). Dissolved $262{ }_{18 \mathrm{PAH}}$ exhibited less spatial variation $(\mathrm{STDEV}=6.3 \mathrm{ng} / \mathrm{L})$ than gaseous ${ }_{15 \mathrm{PAH}}(\mathrm{STDEV}=19.6$ $\left.263 \mathrm{ng} / \mathrm{m}^{3}\right)$. 
Aqueous PAHs were dominated by phenanthrene $(8-41 \%$; <DL $-2.4 \mathrm{ng} / \mathrm{L})$,

265 fluoranthene (9 - 37\%; <DL - $8.7 \mathrm{ng} / \mathrm{L})$, and pyrene (8 - 31\%; <DL - $8.5 \mathrm{ng} / \mathrm{L})$ (Figure S4B).

266 Methylphenanthrenes accounted for $7-11 \%$ of ${ }_{18 \mathrm{PAH}}$ at the offshore sites and $11-35 \%$ of ${ }_{18 \mathrm{PAH}}$

267 at shoreline sites. HMW PAHs accounted for $<2 \%$ of ${ }_{18 \mathrm{PAH}}$ at all sites. Retene accounted for $0.1-$

$2682 \% \quad{ }_{18 \mathrm{PAH}}$ and was greatest in Oswego (NY). The diagnostic ratio Phn/ MPhn ranged from 0.6 at

269 Fairport Harbor and Sheffield Lake to 3.7 at the central and eastern Lake Erie buoy sites. Ratios

270 of Flra/Flra+Pyr were $>0.5$ at all sites except Gibraltar Island (Flra/Flra+Pyr $=0.3, \mathrm{Phn} / \mathrm{MPhn}=$

271 1.2) suggesting that dissolved PAHs originated primarily from combustion, with possible

272 contributions from petroleum spills at Gibraltar. ${ }^{14,33}$

273 PCA results for dissolved PAHs showed locations clustered differently than for gaseous

274 PAH composition, suggesting that source profiles differed for atmospheric and aqueous PAHs.

275 This may be because in addition to atmospheric deposition, runoff and sediment-water exchange

276 contributed to dissolved concentrations. The dissolved PAH profile was most distinct at

277 Sheffield Lake, while Toledo and Buffalo, both expected to be impacted by river discharge, were

278 clustered together (Figure S5).

279 Comparison with Literature Values. Dissolved PAH concentrations were similar to

280 those reported by Ruge for heavily impacted sites on Lake Superior. ${ }^{36}$ Previous work in Lake

281 Michigan reported average total dissolved aqueous $\mathrm{PAH}$ concentrations of $9 \mathrm{ng} / \mathrm{L}$ from

282 shipboard measurements, which was similar to the mean dissolved ${ }_{18 \mathrm{PAH}}$ concentration of all sites

283 in this study $(9.1 \mathrm{ng} / \mathrm{L}) .{ }^{2}$ Concentrations reported here were generally greater than surface waters

284 of Narragansett Bay (RI) ${ }^{14}$ or the Patapsco River (MD), ${ }^{57}$ though maximum concentrations

285 measured on the Patapsco exceeded maximum concentrations measured here. Concentrations

286 were lower than dissolved PAHs in a freshwater lake in China. ${ }^{42} \mathrm{PAH}$ profiles were similar to

287 those reported for Narragansett Bay. ${ }^{14}$ 
289 significant $\left(\mathrm{r}^{2}<0.3, \mathrm{p}>0.05\right)$ for dissolved PAHs, with the exception fluorene $\left(\mathrm{r}^{2}{ }_{15 \mathrm{~km}}=0.36, \mathrm{p}<\right.$ 290 0.05), perylene $\left(\mathrm{r}^{2}{ }_{1 \mathrm{~km}}=0.38, \mathrm{p}<0.01\right)$, and retene $\left(\mathrm{r}^{2}{ }_{1 \mathrm{~km}}=0.59, \mathrm{p}<0.001\right)$. The explanation for 291 correlations observed for these three compounds is unknown. One possible reason for the weak 292 correlation for most aqueous PAHs is that the two most populated sites in downtown Cleveland 293 were absent from the aqueous dataset. Aqueous sampling near Cleveland was not done at the 294 same sites as air sampling, rather PEs were deployed further from shore.

295 The lack of strong correlations also suggests that sources other than atmospheric 296 deposition, such as river discharge and WWTP effluent, could have been significant in 297 determining dissolved PAH concentrations in surface waters. In addition, longer-term reservoirs 298 that are not representative of current emissions, such as PAHs from sediments or from deeper in 299 the water column, could be contributing to surface concentrations so that aqueous concentrations 300 reflect longer term deposition while atmospheric concentrations reflect recent emissions. 301 However, summertime stratification occurring throughout most of the sampling period is 302 expected to reduce the importance of these contributions.

303 Concentrations at offshore Lake Erie sites were greatest in the western basin where the 304 lake is shallowest and inputs from the Detroit and Maumee watersheds, both AOCs, were 305 expected to be significant (Figure S3A). Due to the central Erie basin's counterclockwise 306 circulation during the study season, ${ }^{20}$ it is unlikely that elevated dissolved PAHs in Sheffield 307 Lake resulted from aqueous transport from Cleveland. Black River, a historically polluted AOC, 308 discharges $8 \mathrm{~km}$ west of the Sheffield Lake site and may have contributed to dissolved PAH 309 concentrations there. More measurements over time are needed to determine whether elevated 310 dissolved PAHs at Sheffield Lake were episodic or chronic. Unexpectedly, concentrations near 311 Cleveland were lower than at Sheffield Lake. This may be because of sampler placement, as PEs 
312 at Cleveland were farther offshore where water was deeper and currents carrying more highly

313 impacted water may have been entrained closer to the shore.

314 Besides Sheffield Lake, the greatest dissolved PAHs were measured in Toledo, Buffalo,

315 and Erie. Average dissolved PAH concentrations in Erie sampled from early June to early

316 September were greater $\left({ }_{18 \mathrm{PAH}}=11.4 \mathrm{ng} / \mathrm{L}\right)$ and showed a lower percent contribution from LMW

317 PAHs (Figure S5) than other rural sites, possibly due to contributions from contaminated

318 sediments or WWTP effluent. The Erie site was within the recently delisted Presque Isle Bay

319 AOC, which was dredged for the first time in 20 years during summer of 2011, possibly

320 releasing elevated concentrations of $\mathrm{PAHs}$ into the water column. ${ }^{15,58,59}$ The greatest

321 concentrations were seen during the second deployment, which took place in early fall $\left({ }_{18 \mathrm{PAH}}=\right.$

$32215.6 \mathrm{ng} / \mathrm{L}$ ), perhaps due to the weakening of summertime stratification. The site was also within

$3235 \mathrm{~km}$ of a major ( 150 million liters/day) WWTP (Figure S3A).

324 Air-Water Exchange. Mass transfer coefficients and flux gradients are listed in Tables S11 and

325 S12 and flux gradients for select PAHs are presented in Figure S9. Mass transfer velocity ranged

326 from $0.2 \mathrm{~cm} /$ day to $73 \mathrm{~cm} /$ day and values decreased with decreasing volatility. Uncertainty in

327 flux gradients was $<30 \%$ for all compounds of lower molecular weight than benz(a)anthracene

328 except retene. Flux gradients for HMW PAHs were not different from equilibrium within the

$32995 \%$ confidence level.

330 Net flux rates $\left(\mathrm{ng} / \mathrm{m}^{2} /\right.$ day) are provided in Table S13. Patterns in flux direction were

331 similar to those reported by Bamford et al. in that LMW PAHs were volatilizing and

332 phenanthrene was being absorbed but less volatilization was seen here than in Patapsco River

333 and depositional fluxes of phenanthrene in our study were greater on average. ${ }^{57}$ Fluxes for 
334 acenaphthylene, phenanthrene, methylphenanthrenes, and pyrene at each site were summarized

335 in Figure 5 over three time periods: April - June, June - August, and August - November.

336 Acenaphthylene volatilized from surface waters during most deployments, with

337 volatilization fluxes ranging from $19.3 \mathrm{ng} / \mathrm{m}^{2} /$ day in Niagara to $363 \mathrm{ng} / \mathrm{m}^{2} /$ day in Erie.

338 Phenanthrene was absorbed at all sites with the exception of Niagara during the second

339 deployment, where a volatilization flux of $236 \mathrm{ng} / \mathrm{m}^{2} /$ day was measured. Phenanthrene

340 deposition fluxes ranged from $237 \mathrm{ng} / \mathrm{m}^{2} /$ day at Cape Vincent in early fall to $3271 \mathrm{ng} / \mathrm{m}^{2} / \mathrm{day}$ at

341 Dunkirk in summer. This suggests that during the study period the lakes were primarily a source

342 of acenaphthylene to the overlying atmosphere, while the atmosphere was a source of dissolved

343 phenanthrene to the lakes. However, dissolved phenanthrene concentrations in air and water

344 were not significantly correlated, suggesting that diffusive exchange was not the only mechanism

345 influencing aqueous phenanthrene concentrations. Blanchard et al. estimated annual net

346 absorption of phenanthrene for Lake Erie and Lake Ontario to be $1020 \mathrm{ng} / \mathrm{m}^{2} /$ day and 310

$347 \mathrm{ng} / \mathrm{m}^{2} /$ day, respectively, in $2005 .^{24}$

348 The greatest depositional fluxes were measured at Dunkirk and Grimsby, particularly

349 during June - August. Though average temperatures during deployment were warm (17 - 21.4

$350{ }^{\circ} \mathrm{C}$ ), all PAHs except acenaphthylene were absorbed at these sites. Deposition at Grimsby 351 suggests that the Toronto/Hamilton conurbation acted as a source of dissolved PAHs to the open

352 water. Deposition at Dunkirk was likely driven by the greater gaseous PAH concentrations at this 353 site and clean surface waters.

354 At Erie, Niagara, Sheffield, and Buffalo (second deployment only), the majority of PAHs 355 were volatilizing. Erie and Sheffield exhibited the strongest volatilization, driven by elevated 
aqueous concentrations. The greatest volatilization fluxes measured at the two sites were for

357 fluoranthene (927 ng/m²/day at Erie, $879 \mathrm{ng} / \mathrm{m}^{2} /$ day at Sheffield Lake) and pyrene (591

$358 \mathrm{ng} / \mathrm{m}^{2} /$ day at Erie, $857 \mathrm{ng} / \mathrm{m}^{2} /$ day at Sheffield Lake). Volatilization was comparable at the two

359 sites, though anthracene and benz(a)anthracene volatilized more strongly at Sheffield Lake.

360 Lohmann et al. observed volatilization of PAHs in an urbanized portion of Narragansett Bay (RI)

361 and suggested that river input and runoff were more significant sources of dissolved PAHs than

362 atmospheric deposition. ${ }^{14}$ Volatilization at Niagara may indicate that river discharge was a

363 significant source of PAHs at these sites.

364 Air-water exchange is strongly influenced by air temperature, wind speed, and wind

365 direction and large daily variations in fluxes have been observed. ${ }^{57}$ During deployments where

366 mean temperature was greater than $19^{\circ} \mathrm{C}$, phenanthrene and anthracene were the only PAHs

367 being absorbed into surface waters, with the exception of measurements from Oswego $\left(3^{\text {rd }}\right.$

368 deployment) as well as Dunkirk. In Buffalo, most PAH fluxes changed from net deposition

369 during the first deployment (mean temperature of $11^{\circ} \mathrm{C}$ ) to net volatilization during the second

370 deployment (mean temperature $19-20.5^{\circ} \mathrm{C}$ ). During the third deployment, most fluxes were not

371 significantly different from equilibrium. In Oswego, the temperature dependency observed in

372 Buffalo was not evident.

\section{IMPLICATIONS}

374 Strong correlation with population suggests that urban centers played an important role in

375 determining spatial distributions of gaseous PAHs. However, air-water fluxes and distributions

376 of dissolved PAHs implied that additional sources beyond diffusive exchange influenced

377 aqueous distributions, especially in urban areas. In some cases surface waters acted as a source

378 of PAHs to the atmosphere. Enhanced spatial coverage near AOCs and major urban areas like 
379 Toronto, as well as consistent temporal coverage, could help explain how river discharge, 380 sediment-water exchange, WWTP effluent, and other sources influence dissolved PAH 381 concentrations in the lower Great Lakes.

\section{ASSOCIATED CONTENT}

383 Supporting Information. Detailed information on sampler deployments, site characteristics, and 384 compound properties can be found along with calculated sampling rates, table of concentrations, 385 and plots describing the results of principal component analysis. This material is available free of 386 charge via the Internet at http://pubs.acs.org.

\section{AUTHOR INFORMATION}

388 Corresponding Author. Rainer Lohmann

389 Author Contributions. The manuscript was written through contributions of all authors. All

390 authors have given approval to the final version of the manuscript.

\section{ACKNOWLEDGMENTS}

392 We would like to acknowledge funding from the US EPA Great Lakes Restoration Initiative 393 GLAS \#00E00597-0, project officer Todd Nettesheim. We would like to thank Peter August 394 (URI) for assistance with GIS, David Adelman (URI) for organizing deployments, Camilla 395 Teixeira and the field staff of the Emergencies, Operational Analytical Laboratories, and 396 Research Support group (Environment Canada Burlington) for open-lake deployments, Zoe 397 Ruge (URI) for assistance with data analysis and interpretation, Ali Brandeis (URI) for helping 398 with extractions, and all of the volunteers who deployed PEs in the region.

\section{REFERENCES}


(1) Brown, A. S.; Brown, R. J. C. Correlations in polycyclic aromatic hydrocarbon (PAH) concentrations in UK ambient air and implications for source apportionment. J. Environ. Monit. 2012, 14, 2072-2082, DOI:10.1039/c2em10963h.

(2) Simcik, M. F.; Eisenreich, S. J.; Lioy, P. J. Source apportionment and source/sink relationships of PAHs in the coastal atmosphere of Chicago and Lake Michigan. Atmos. Environ. 1999, 33, 5071-5079, DOI:10.1016/S1352-2310(99)00233-2.

(3) Shen, H.; Huang, Y.; Wang, R.; Zhu, D.; Li, W.; Shen, G.; Wang, B.; Zhang, Y.; Chen, Y.; Lu, Y.; Chen, H.; Li, T.; Sun, K.; Li, B.; Liu, W.; Liu, J. Global Atmospheric Emissions of Polycyclic Aromatic Hydrocarbons from 1960 to 2008 and Future Predictions. Environ. Sci. Technol. 2013, 47, 6415-6424, DOI:10.1021/es400857z.

(4) Melymuk, L.; Robson, M.; Helm, P. A.; Diamond, M. L. Application of land use regression to identify sources and assess spatial variation in urban SVOC concentrations. Environ. Sci. Technol. 2013, 47, 1887-1895, DOI:10.1021/es3043609.

Galarneau, E.; Makar, P. A.; Sassi, M.; Diamond, M. L. Estimation of atmospheric emissions of six semivolatile polycyclic aromatic hydrocarbons in southern canada and the United States by use of an emissions processing system. Environ. Sci. Technol. 2007, 41, 4205-4213, DOI:10.1021/es062303k.

(6) Melymuk, L.; Robson, M.; Helm, P. A.; Diamond, M. L. PCBs, PBDEs, and PAHs in Toronto air: spatial and seasonal trends and implications for contaminant transport. Sci. Total Environ. 2012, 429, 272-280, DOI:10.1016/j.scitotenv.2012.04.022.

(7) Hafner, W.; Hites, R. Potential sources of pesticides, PCBs, and PAHs to the atmosphere of the Great Lakes. Environ. Sci. Technol. 2003, 37, 3764-3773, DOI:10.1021/es034021f.

(8) Grimmer, G.; Brune, H.; Dettbarn, G.; Jacob, J.; Misfeld, J.; Mohr, U.; Naujack, K.-W.; Timm, J.; Wenzel-Hartung, R. Relevance of polycyclic aromatic hydrocarbons as environmental carcinogens. Fresenius J. Anal. Chem. 1991, 339, 792-795, DOI:10.1007/BF00321747.

(9) Boström, C.-E.; Gerde, P.; Hanberg, A.; Jernström, B.; Johansson, C.; Kyrklund, T.; Rannug, A.; Törnqvist, M.; Victorin, K.; Westerholm, R. Cancer risk assessment, indicators, and guidelines for polycyclic aromatic hydrocarbons in the ambient air. Environ. Health Perspect. 2002, $110 \mathrm{Suppl}, 451-488$.

(10) Adams, R. G.; Lohmann, R.; Fernandez, L. A.; Macfarlane, J. K.; Gschwend, P. M. Polyethylene Devices: Passive Samplers for Measuring Dissolved Hydrophobic Organic Compounds in. Environ. Sci. Technol. 2007, 41, 1317-1323, DOI:10.1021/es0621593.

(11) Khairy, M. A.; Lohmann, R. Field validation of polyethylene passive air samplers for parent and alkylated PAHs in Alexandria, Egypt. Environ. Sci. Technol. 2012, 46, 39903998, DOI:10.1021/es300012u. 
(12) Allan, I. J.; Harman, C.; Ranneklev, S. B.; Thomas, K. V; Grung, M. Passive sampling for target and nontarget analyses of moderately polar and nonpolar substances in water. Environ. Toxicol. Chem. 2013, 32, 1718-1726, DOI:10.1002/etc.2260.

(13) Sacks, V. P.; Lohmann, R. Freely dissolved PBDEs in water and porewater of an urban estuary. Environ. Pollut. 2012, 162, 287-293, DOI:10.1016/j.envpol.2011.11.028.

(14) Lohmann, R.; Dapsis, M.; Morgan, E. J.; Dekany, V.; Luey, P. J. Determining air-water exchange, spatial and temporal trends of freely dissolved PAHs in an urban estuary using passive polyethylene samplers. Environ. Sci. Technol. 2011, 45, 2655-2662, DOI:10.1021/es1025883.

(15) Morgan, E. J.; Lohmann, R. Detecting air-water and surface-deep water gradients of PCBs using polyethylene passive samplers. Environ. Sci. Technol. 2008, 42, 7248-7253, DOI:10.1021/es800518g.

(16) Lohmann, R.; Klánová, J.; Kukucka, P.; Yonis, S.; Bollinger, K. Concentrations, Fluxes, and Residence Time of PBDEs Across the Tropical Atlantic Ocean. Environ. Sci. Technol. 2013, 47, 13967-13975, DOI:10.1021/es403494b.

(17) Quinn, F. H. Hydraulic Residence Times for the Laurentian Great Lakes. J. Gt. Lakes Res. 1992, 18, 22-28, DOI:10.1016/S0380-1330(92)71271-4.

(18) NY Sea Grant; Domske, H. M. "Lake Erie Factsheet" http://www.seagrant.sunysb.edu/Images/Uploads/PDFs/LakeErieFactSheet0413.pdf (accessed Feb 13, 2014).

(19) Environment Canada; US EPA. The Great Lakes: An Environmental Atlas and Resource Book, 3rd Ed. http://www.epa.gov/glnpo/atlas/ (accessed Feb 13, 2014).

(20) Beletsky, D.; Saylor, J. H.; Schwab, D. J. Mean Circulation in the Great Lakes. J. Great Lakes Res. 1999, 25, 78-93, DOI:10.1016/S0380-1330(99)70718-5.

(21) Salamova, A.; Pagano, J. J.; Holsen, T. M.; Hites, R. A. Post-1990 Temporal Trends of PCBs and Organochlorine Pesticides in the Atmosphere and in Fish from Lakes Erie, Michigan, and Superior. Environ. Sci. Technol. 2013, 47, 9109-9114, DOI:10.1021/es401895g.

(22) Melymuk, L.; Robson, M.; Csiszar, S. A.; Helm, P. A.; Kaltenecker, G.; Backus, S.; Bradley, L.; Gilbert, B.; Blanchard, P.; Jantunen, L. M.; Diamond, M. L. From the City to the Lake: Loadings of PCBs, PBDEs, PAHs and PCMs from Toronto to Lake Ontario. Environ. Sci. Technol. 2014, DOI:10.1021/es403209z.

(23) Sun, P.; Blanchard, P.; Brice, K. A.; Hites, R. A. Trends in polycyclic aromatic hydrocarbon concentrations in the Great Lakes atmosphere. Environ. Sci. Technol. 2006, 40, 6221-6227, DOI:10.1021/es0607279. 
(24) Blanchard, P.; Audette, C. V.; Hulting, M. L.; Basu, I.; Brice, K. A.; Backus, S. M.; Dryfhout-Clark, H.; Froude, F.; Hites, R. A.; Neilson, M.; Wu, R. Atmospheric deposition of toxic substances to the Great Lakes: IADN results through 2005, Published by Environment Canada and the United States Environmental Protection Agency, 2005.

(25) Swackhamer, D. L.; Schottler, S.; Pearson, R. F. Air-Water Exchange and Mass Balance of Toxaphene in the Great Lakes. Environ. Sci. Technol. 1999, 33, 3864-3872, DOI:10.1021/es990280m.

(26) Baker, J. E.; Eisenreich, S. J. Concentrations and Fluxes of Polycyclic Aromatic Hydrocarbons and Polychlorinated Biphenyls across the Air-Water Interface of Lake Superior. Environ. Sci. Technol. 1990, 24, 342-352, DOI:10.1021/es00073a009.

(27) Booij, K.; Smedes, F.; van Weerlee, E. M. Spiking of performance reference compounds in low density polyethylene and silicone passive water samplers. Chemosphere 2002, 46, 1157-1161, DOI:10.1016/S0045-6535(01)00200-4.

(28) NOAA National Data Buoy Center Historical Archive http://www.ndbc.noaa.gov/hmd.shtml (accessed Dec 15, 2013).

(29) Minar, N. Wind History http://windhistory.com/ (accessed Dec 15, 2013).

(30) NOAA. NOAA National Climatic Data Center http://www.ncdc.noaa.gov/ (accessed Feb 1, 2014).

(31) Lohmann, R. Critical review of low-density polyethylene's partitioning and diffusion coefficients for trace organic contaminants and implications for its use as a passive sampler. Environ. Sci. Technol. 2012, 46, 606-618, DOI:10.1021/es202702y.

(32) Booij, K.; Smedes, F. An Improved Method for Estimating in Situ Sampling Rates of Nonpolar. Environ. Sci. Technol. 2010, 44, 6789-6794, DOI:10.1021/es101321v.

(33) Yunker, M. B.; Macdonald, R. W.; Vingarzan, R.; Mitchell, R. H.; Goyette, D.; Sylvestre, S. PAHs in the Fraser River basin: a critical appraisal of PAH ratios as indicators of PAH source and composition. Org. Geochem. 2002, 33, 489-515, DOI:10.1016/S01466380(02)00002-5.

(34) Ramdahl, T. Retene - a molecular marker of wood combustion in ambient air. Nature 1983, 306, 580-582, DOI:10.1038/306580a0.

(35) Leppanen, H.; Oikari, A. Occurrence of retene and resin acids in sediments and fish bile from a lake receiving pulp and paper mill effluents. Environ. Toxicol. Chem 1999, 18, 1498-1505, DOI:10.1002/etc.5620180723.

(36) Ruge, Z. Air-water exchange and trends of persistent bioaccumulative toxics (PBTs) across Lake Superior. Master's Thesis., University of Rhode Island, 2013. 
(37) Husson, F.; Josse, J.; Le, S.; Mazet, J. FactoMineR http://factominer.free.fr (accessed Jan 2, 2014).

(38) R Core Team. R: A language and environment for statistical computing (version 3.1.0), 2014.

(39) US EPA. TRI NET http://www.epa.gov/tri/tridotnet/index.html (accessed Jan 11, 2013).

(40) Cheng, J.-O.; Ko, F.-C.; Lee, C.-L.; Fang, M.-D. Air-water exchange fluxes of polycyclic aromatic hydrocarbons in the tropical coast, Taiwan. Chemosphere 2012, 90, 2614-2622, DOI:10.1016/j.chemosphere.2012.11.020.

(41) Barrado, A. I.; García, S.; Sevillano, M. L.; Rodríguez, J. A.; Barrado, E. Vapor-phase concentrations of PAHs and their derivatives determined in a large city: Correlations with their atmospheric aerosol concentrations. Chemosphere 2013, 93, 1-7, DOI:10.1016/j.chemosphere.2013.05.031.

(42) Qin, N.; He, W.; Kong, X.-Z.; Liu, W.-X.; He, Q.-S.; Yang, B.; Ouyang, H.-L.; Wang, Q.M.; Xu, F.-L. Atmospheric partitioning and the air-water exchange of polycyclic aromatic hydrocarbons in a large shallow Chinese lake (Lake Chaohu). Chemosphere 2013, 93, 1685-1693, DOI:10.1016/j.chemosphere.2013.05.038.

(43) Arinaitwe, K.; Kiremire, B. T.; Muir, D. C. G.; Fellin, P.; Li, H.; Teixeira, C.; Mubiru, D. N. Atmospheric Concentrations of Polycyclic Aromatic Hydrocarbons in the Watershed of Lake Victoria, East Africa. Environ. Sci. Technol. 2012, 46, 11524-11531, DOI:10.1021/es302238w.

(44) Atkinson, R.; Arey, J. Atmospheric chemistry of gas-phase polycyclic aromatic hydrocarbons: formation of atmospheric mutagens. Environ. Health Perspect. 1994, 102, 117-126, DOI:10.2307/3431940.

(45) Bunce, N. J.; Dryfhout, H. G. Diurnal and seasonal modeling of the tropospheric half-lives of polycyclic aromatic hydrocarbons. Can. J. Chem 1992, 70, 1966-1970, DOI:10.1139/v92-246.

(46) Brubaker, W. W.; Hites, R. A. OH Reaction Kinetics of Polycyclic Aromatic Hydrocarbons and Polychlorinated Dibenzo-p-dioxins and Dibenzofurans. J. Phys. Chem. A. 1998, 102, 915-921, DOI:10.1021/jp9721199.

(47) Galarneau, E.; Bidleman, T. F.; Blanchard, P. Seasonality and interspecies differences in particle/gas partitioning of PAHs observed by the Integrated Atmospheric Deposition Network (IADN). Atmos. Environ. 2006, 40, 182-197, DOI:10.1016/j.atmosenv.2005.09.034.

(48) Offenberg, J. H.; Baker, J. E. The influence of aerosol size and organic carbon content on gas/particle partitioning of polycyclic aromatic hydrocarbons (PAHs). Atmos. Environ. 2002, 36, 1205-1220, DOI:10.1016/S1352-2310(01)00427-7. 
(49) Simcik, M. F. Gas-Particle Partitioning of PCBs and PAHs in the Chicago Urban and Adjacent Coastal Atmosphere: States of Equilibrium. Environ. Sci. Technol. 1998, 32, 251-257, DOI:10.1021/es970557n.

(50) Paasivirta, J.; Sinkkonen, S.; Mikkelson, P.; Rantio, T.; Wania, F. Estimation of vapor pressures, solubilities, and Henry's Law constants of selected persistent organic pollutants as functions of temperature. Chemosphere 1999, 39, 811-832, DOI:10.1016/S00456535(99)00016-8.

(51) Lohmann, R.; Harner, T.; Thomas, G. O.; Jones, K. C. A Comparative Study of the GasParticle Partitioning of PCDD/Fs, PCBs, and PAHs. Environ. Sci. Technol. 2000, 34, 4943-4951, DOI:10.1021/es9913232.

(52) Su, Y.; Lei, Y. D.; Wania, F.; Shoeib, M.; Harner, T. Regressing gas/particle partitioning data for polycyclic aromatic hydrocarbons. Environ. Sci. Technol. 2006, 40, 3558-3564, DOI:10.1021/es052496w CCC:

(53) Gustafson, K. E.; Dickhut, R. M. Particle / Gas Concentrations and Distributions of PAHs in the Atmosphere of Southern Chesapeake. Environ. Sci. Technol. 1997, 31, 140-147, DOI:10.1021/es9602197.

(54) Bidleman, T. F. Atmospheric processes - Wet and Dry Deposition. Environ. Sci. Technol. 1988, 22, 361-367, DOI:10.1021/es00169a002.

(55) Akyüz, M.; Çabuk, H. Gas - particle partitioning and seasonal variation of polycyclic aromatic hydrocarbons in the atmosphere of Zonguldak , Turkey. Sci. Total Environ. 2010, 408, 5550-5558, DOI:10.1016/j.scitotenv.2010.07.063.

(56) Hafner, W.; Carlson, D.; Hites, R. Influence of local human population on atmospheric polycyclic aromatic hydrocarbon concentrations. Environ. Sci. Technol. 2005, 39, 73747379, DOI:10.1021/es0508673.

(57) Bamford, H. A.; Offenberg, J. H.; Larsen, R. K.; Ko, F.; Baker, J. E. Diffusive Exchange of Polycyclic Aromatic Hydrocarbons across the Air - Water Interface of the Patapsco River, an Urbanized Subestuary of the Chesapeake Bay. Environ. Sci. Technol. 1999, 33, 2138-2144, DOI:10.1021/es981324e.

(58) US EPA. Great Lakes Areas of Concern http://www.epa.gov/glnpo/aoc/ (accessed Nov 2, 2014).

(59) Martin, J. "Dredging barge goes to work in Presque Isle Bay", Erie Times News http://www.goerie.com (accessed Dec 3, 2013). 

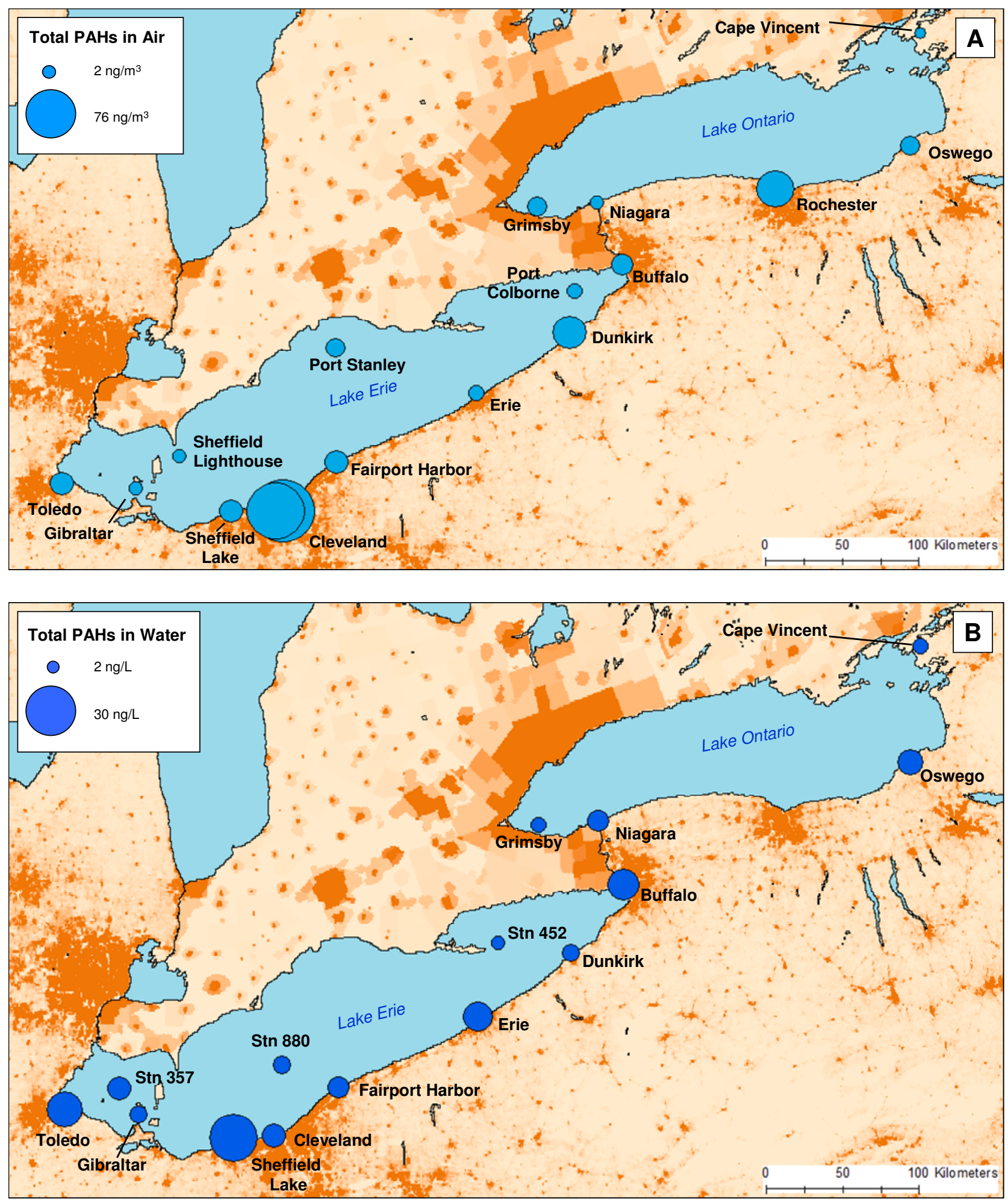
578 Figure 1. PAH Concentrations in Air (A) and Water (B). Average gaseous ${ }_{15 \mathrm{PAH}}(\mathrm{A})$ and 579 dissolved ${ }_{18 \mathrm{PAH}}(\mathrm{B})$ in Lake Erie and Lake Ontario. Orange shading delineates population centers.

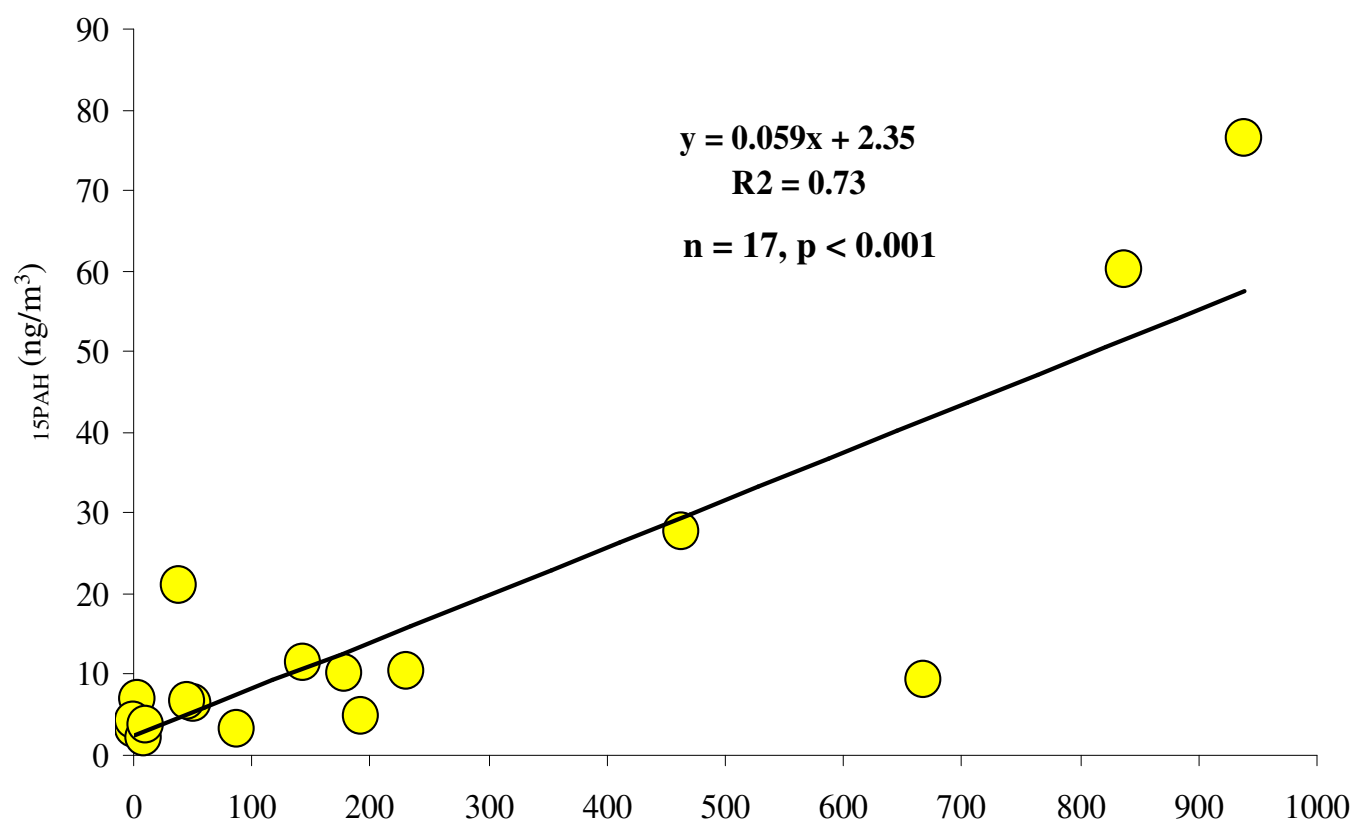

Thousands of People within $20 \mathrm{~km}$ Radius

581 Figure 2. Atmospheric ${ }_{15 \mathrm{PAH}}$ and Population within $20 \mathrm{~km}$. Average atmospheric

582 concentrations of gaseous PAHs at each site correlated well with population within $20 \mathrm{~km}$. The 583 two sites in downtown Cleveland exhibited the greatest ${ }_{15 \mathrm{PAH}}$ concentrations while concentrations 584 in Buffalo were lower than would be predicted by the regression. 

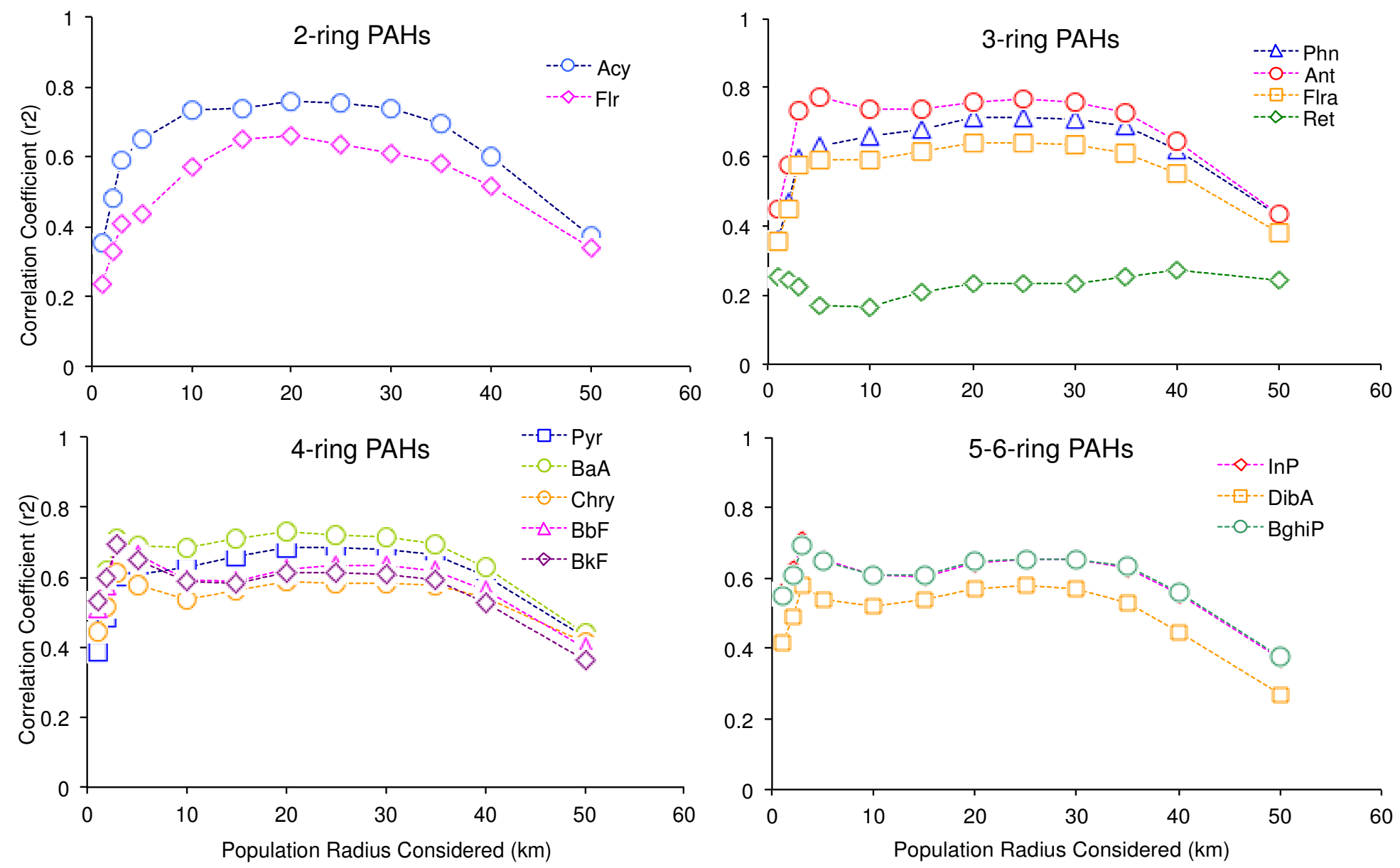

Figure 3. Correlation Strength Varies with Population Radius Considered. Depending on the radius used to calculate population at each site, the strength of correlation (depicted using the coefficient of determination, $\mathrm{r}^{2}$ ) between gaseous PAH concentration and 
population varied, displaying a bimodal relationship. The radius of maximum correlation was similar for PAH molecules of similar size. 


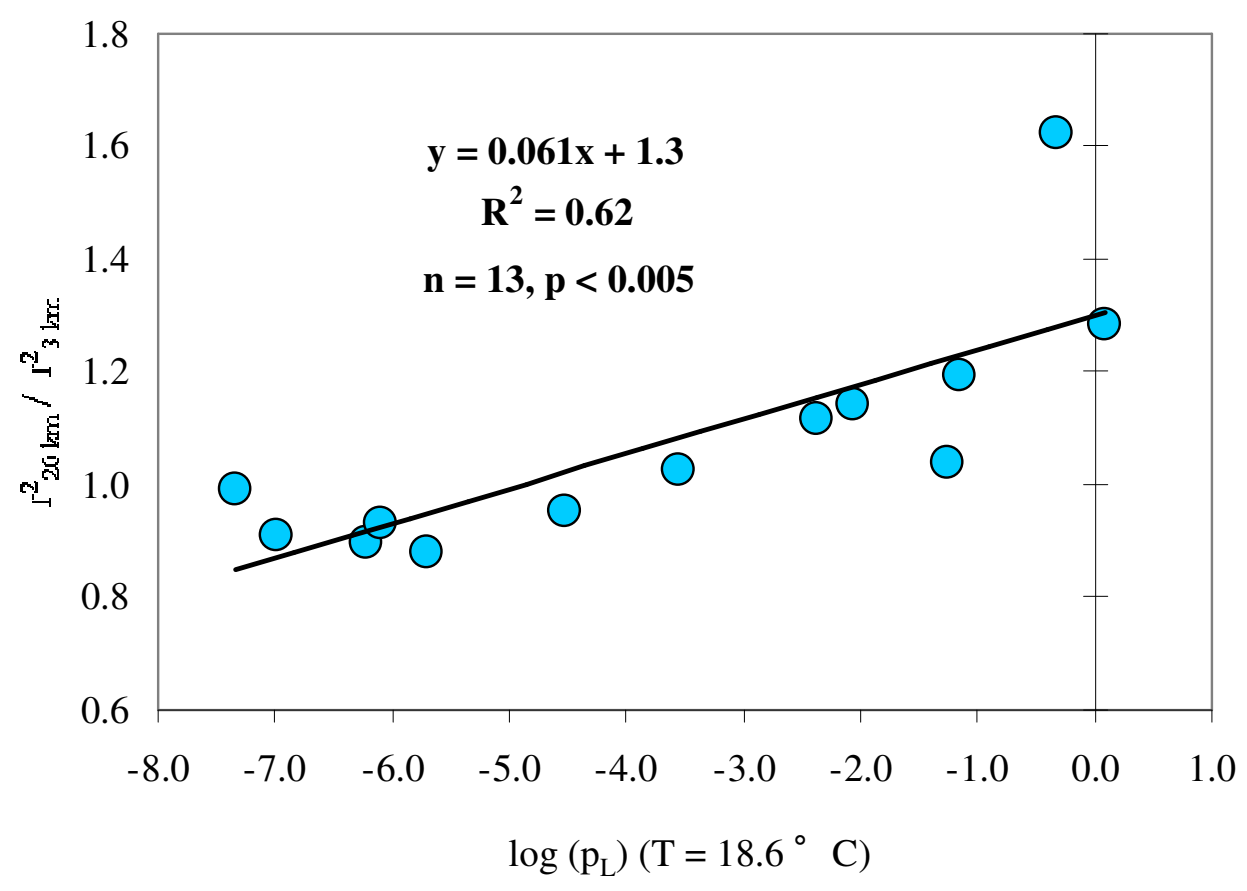

Figure 4. Relative significance of population within $20 \mathrm{~km}$ and $3 \mathbf{k m}$. The ratio of $r_{20 \mathrm{~km}}^{2}$ to $r_{10}^{2}$ ${ }_{\mathrm{km}}$ correlated well with sub-cooled liquid vapor pressure at mean deployment temperature, suggesting that distant sources were more significant for volatile PAHs. 


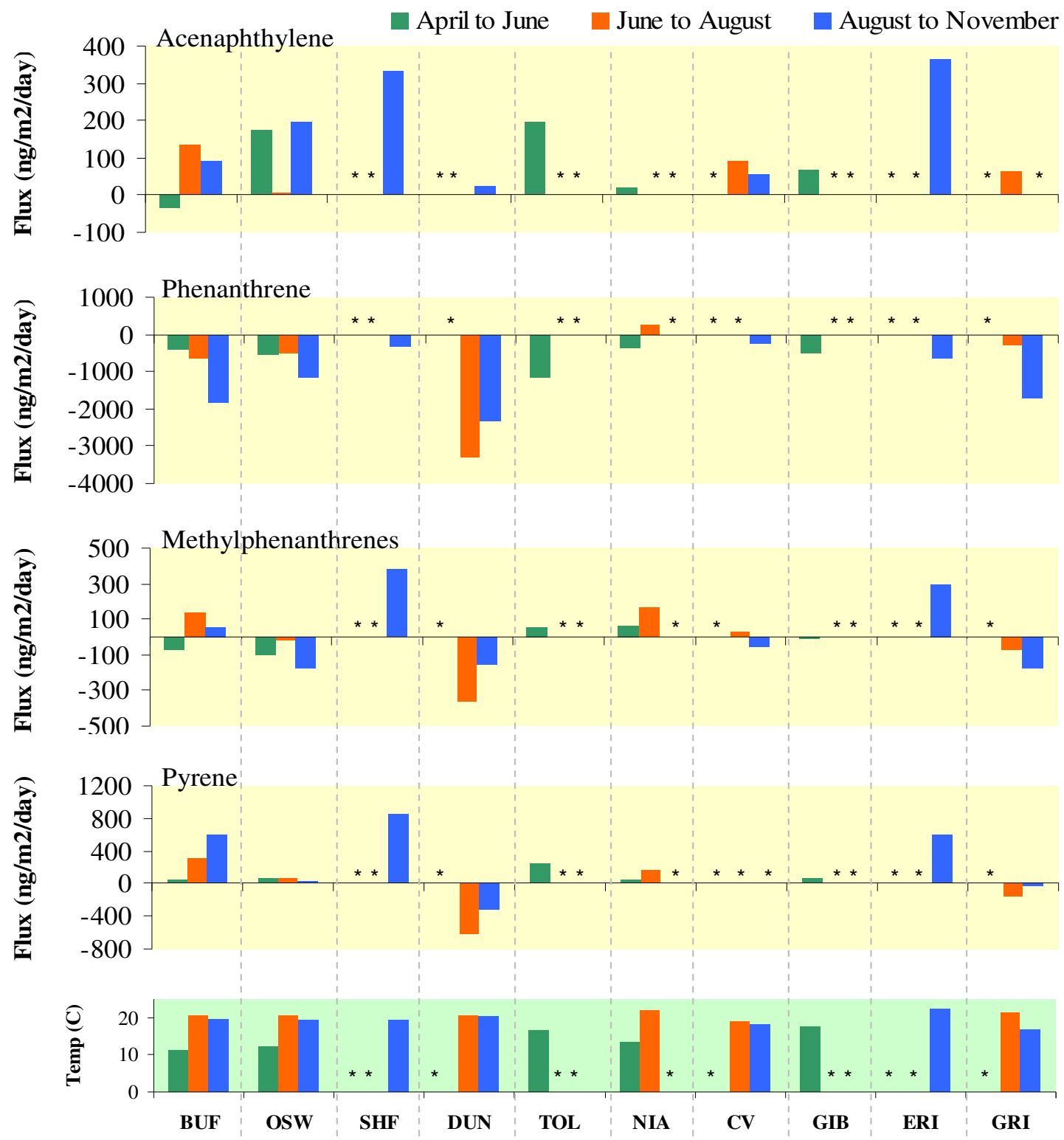

2 Figure 5. Net Air-Water Flux of Four PAHs. Air-water fluxes (ng/m²/day) for four PAHs

3 during three deployment periods with mean air temperature at the bottom. Negative values

4 indicate absorption into surface waters while positive values indicate volatilization. Sites where

5 no data was available or air and water concentrations were both $<$ DL are marked with *. 


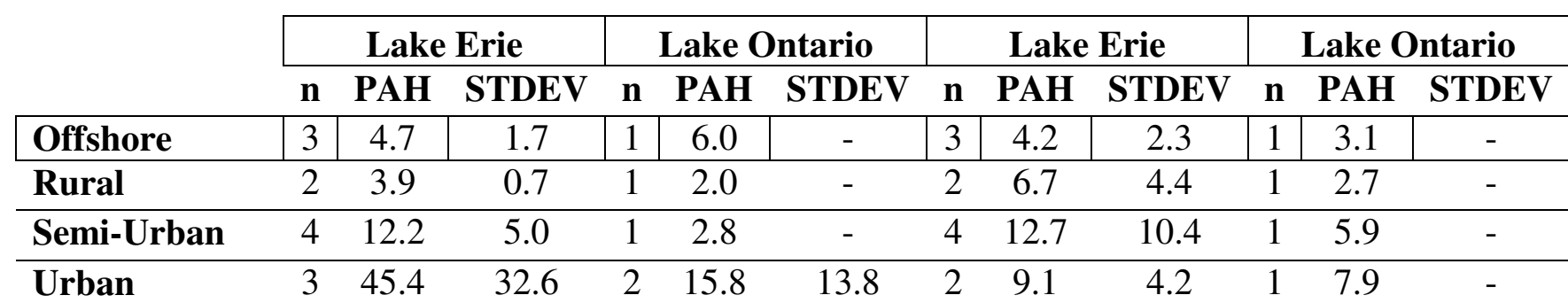

8

9 Table 1. Average Gaseous and Dissolved $\Sigma_{\mathrm{PAH}}$ Concentrations in Lake Erie and Lake

10 Ontario. The number of sites within each category (n) is listed along with mean PAH

11 concentrations and standard deviation. Sites were classified based on population within $3 \mathrm{~km}$ to

12 facilitate comparison between lakes: 0-100 people: Offshore; 100-1000: Rural; 1000-10,000:

13 Semi-urban; >10,000: Urban.

14 